\title{
Teaching students about ergonomics
}

\section{David Hutchison}

$\mathrm{I}$ n keeping with this issue's focus on health, safety, and the wellness of students in school, this article explores an oftenoverlooked issue related to children's daily use of computer technology in schools. While Boards of Education routinely herald their latest computer and technology purchases, the potential ergonomic challenges posed by computers often remain unaddressed. This article looks briefly at the ergonomics issue, highlights some of the health issues involved, and suggests a couple of ergonomicsrelated activities teachers can implement.

In their critique of computers in schools, Armstrong and Casement (1998) offer this Canadian example in support of their argument that not enough attention is paid to ergonomics in schools:

"While visiting a computer lab with my daughter and her grade two class, I watched while the children got a crash course in the use of various software programs. Although the chairs swiveled and were adjustable, they had clearly been made for adult bodies... Missing from the lesson was any guidance on correct hand and body posture at the keyboard. No one mentioned that the chairs were adjustable and could be made more comfortable for children of different sizes... The equipment was completely out of proportion for virtually the entire group of seven-year-olds. Consequently, all of these children spent the morning with their heads tilted upwards at the screen in a posture designed to put strain on the spine and give them sore necks. ( $p$. 154)."

For budgetary and efficiency reasons, most schools purchase generic furniture which is then used for multiple purposes and age groups. Yet there is a growing awareness of the need to ensure that the design of tables, chairs, and other furniture conform to ergonomically acceptable standards and that the specific purposes to which school furniture is put is both age and use appropriate (Perkins, 2001).

The science of ergonomics has emerged from relative obscurity in the early decades of the twentieth century to highlight one of the most important technologyrelated health issues of the early twenty-first century. As increasing numbers of adults spend more and more time in front of computers in offices and other workplace environments, there has emerged a pressing concern for the rising number of office workers who are afflicted with carpal tunnel syndrome, otherwise known as repetitive stress injury. In addition, while it is the practical implications of ergonomics to the workplace that have received the most attention, there are important lessons for teachers and for parents.

Consider, for example, the redeployment of traditional desks and other furniture to serve as computer tables in schools (Buck, 1994). Many schools spend thousands or even tens of thousands of dollars annually to equip their computer labs and classrooms with the latest computer hardware and software, but the tables on which this equipment is placed are often an afterthought. Classroom computer use by students at every level has and continues to increase exponentially. However, the desks for this equipment are often of fixed height, putting the computer keyboard, mouse, and monitor at an awkward angle for those children who are too short or too tall to work comfortably over extended periods of in class time. Moreover, the chairs that students sit on are unlikely to be adjustable in height. With young children spending increasing amounts of time at the computer, advocates of ergonomic furniture argue that there is an urgent need to resurrect a concern for the design of school furniture, and to renew a commitment to making child-scaled furniture that is both ergonomic, age, and use appropriate.

Here are four activity ideas that teachers can use in schools to teach students about ergonomics:

1. Give a demonstration lesson in which a student volunteer demonstrates both proper and improper postures for sitting at a computer. Pay close attention to the height of the chair, the straightness of the back, the placement of the keyboard, and the sight line of the computer monitor. Many books and web sites about ergonomics feature 
photographs or illustrations that visually depict both good and bad postures (e.g. http:// www.orosha.org/cergos/). Consider photocopying a few of these images and distributing them to the class prior to or following the lesson. Talk with students about common bodily stress points (e.g. the lower and upper back, shoulders, and wrists) and the importance of taking regular breaks from computer use.

2. Ask older students to research the science of ergonomics. Students can review both web sites and books to find information related to the history of ergonomic research, the diagnosis and treatment of ergonomic injuries, and ergonomic technologies that serve to alleviate stress and injury to the body (e.g. ergonomic chairs, back supports, and mouse pads etc.)

3. Talk with students about their video game playing habits. What types of gaming systems do students regularly play (e.g. PC, console, or handheld) and what is their posture like when they are playing games? Encourage students to take regular breaks from gaming and to pay close attention to aches and pains - these are important physical messages that their bodies are sending them. Use this discussion as an opportunity to introduce students to the topic of repetitive stress injury since most video games feature lots of repetitive fine motor movements.

4. Invite an older group of students to conduct an "ergonomic audit" of the school's computer lab. Students can investigate traditional ergonomic issues, but also choose to broaden their analysis to include the lighting, temperature, and noise conditions of the lab as well. Have students investigate if labs have fixed seating or if the chairs can be raised and lowered to accommodate varying student needs? Check to see if the "mice" are appropriately positioned to accommodate lefthanded computer users? Is there enough room and cord length to comfortably use the mice and keyboards? Can the monitors be easily maneuvered to adjust to the sight lines of users?

Answers to these and other questions can be used as the basis for a report that can then be presented to the principal and school staff with recommendations for improving the ergonomics of the computer lab.

The above activities and, indeed, the science of ergonomics itself, is only the tip of the iceberg when it comes to managing health-related issues in schools. Ergonomic challenges are exacerbated by a lack of nutrition, a sedentary lifestyle with little or no exercise, poor lighting conditions in classrooms, poor air quality and circulation, chemical containments in schools (e.g. cleaning supplies), the poor upkeep of school buildings, and asbestos in schools etc. Much research and appropriate intervention is needed to address these and other issues that affect student health and safety in schools.

\section{References}

Armstrong, A., and Casement, C. (1998). The child and the machine: Why computers may put our children's education at risk. Toronto: Key Porter Books.

Buck, G. (1994). Schools ways (Book review). Alberta Journal of Educational Research, XL(1), 95-99.
Computer Ergonomics for Elementary School (http://www.orosha.org/ cergos/)

Hutchison, D. (2004). A natural history of place in education. New York: Teachers College Press.

Ontario Healthy Schools Coalition. (2005). Achieving the vision of healthy schools across Ontario: Priority areas for action. Toronto: Ontario Healthy Schools Coalition. (http:// www.opha.on.ca/resources/OHSCReport-8Jun05.pdf)

Perkins, L. B. (2001). Building type basics for elementary and secondary schools. New York: J. Wiley \& Sons.

Ritter, Jana. (2003). Computer ergonomics: Strategies for safe classrooms and healthy learners. The Galt Global Review, May 20. (http:// www.galtglobalreview.com/careers/ computer_ergonomics.html)

School Health Research (http:// www.schoolhealthresearch.org)

David Hutchison, Ph.D. is an Associate Professor in the Faculty of Education, Brock University (On-

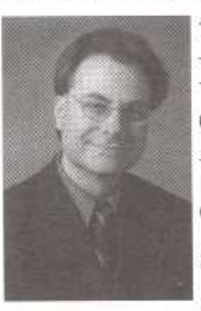
tario, Canada) where he teaches courses in educational foundations (history of education) and social studies. David is the author of two books and many articles in the fields of environmental education and the philosophy of place. Growing Up Green: Education for Ecological Renewal was published in 1998. A Natural History of Place in Education was released in the spring of 2004 .

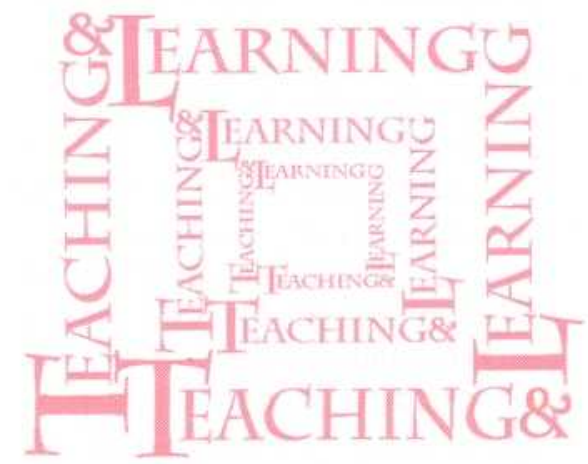

